\title{
Antiproliferative Effect of Ornithogalum balansae on Human Cancer Cell Lines
}

\author{
N. EJDER, S. EKŞi ${ }^{\star}$, Z.A. YAZICI, FŞ. BERIŞ ${ }^{1}$, S. MAKBUL ${ }^{1}$ AND B. UZUNOK ${ }^{2}$
}

Department of Medical Microbiology, Faculty of Medicine, Turkey, ${ }^{1}$ Department of Botanics, Faculty of Arts and Sciences, Recep Tayyip Erdoğan University, Rize, Turkey, ${ }^{2}$ Department of medical Physiology, Faculty of Medicine, Uşak University, Uşak, Turkey

\section{EJDER et al.: Growth Inhibitory Effect of Ornithogalum balansae Extracts}

\begin{abstract}
The purpose of this study was to investigate the antiproliferative effect of the methanol and ethyl acetate extracts of Ornithogalum balansae flower and bulb against normal ARPE-19 cell line and cancer cell lines, A549, CRL-2923, HT-29 and HeLa. The cytotoxic activities of the extracts were determined using cell viability, deoxyribonucleic acid fragmentation and caspase-3 activity tests. Flower and bulb extracts exhibited dose-dependent antiproliferative effects on non-transformed and transformed cells, with greater growth inhibition in A549 lung cancer cells at lower concentrations. The $\mathrm{IC}_{50}$ values of the flower extracts against $A 549$ cells were $1.5 \pm 0.153$ and $2.2 \pm 0.503 \mu \mathrm{g} / \mathrm{ml}$, and of the bulb extracts were $1.8 \pm 0.220$ and $1.56 \pm 0.106 \mu \mathrm{g} / \mathrm{ml}$, respectively. Against ARPE-19 cell line the $\mathrm{IC}_{50}$ values were $22.5 \pm 6.466$ and $25 \pm 2.887$ $\mu \mathrm{g} / \mathrm{ml}$ for flower and $14 \pm 4.726$ and $12.5 \pm 3.182 \mu \mathrm{g} / \mathrm{ml}$ for bulb extracts, respectively. In addition, it was observed that at concentrations $\leq 3.12 \mu \mathrm{g} / \mathrm{ml}$ there were statistically significant differences between ARPE19 and transformed $A 549$ cell lines $(p<0.05)$. Finding caspase-3 activity of the methanol flower extract in A549 indicated apoptotic effects in those cells. These results showed that Ornithogalum balansae extracts could exhibit antitumor activity particularly on the A549 lung cancer cell line, a resistant cell line. Further investigations of the composition of the extracts are required to identify the effective components with antiproliferative activity, particularly on A549, the human alveolar adenocarcinoma cancer cell line. This study revealed that extracts of Ornithogalum balansae possessed considerable antiproliferative activity against A549 cells.
\end{abstract}

Key words: Ornithogalum balansae, cancer, A549 cells, cytotoxicity, apoptosis

Cancer, the second most important cause of death worldwide, is characterized by abnormal cell growth ${ }^{[1]}$. According to the World Health Organization (WHO) report for 2018, one in every six deaths across the World (9.6 million individuals) was due to cancer ${ }^{[2]}$. The costly and toxic nature of today's therapeutic methods, combined with multi-drug resistance, prevent cancer treatment from reaching the desired outcomes. Drugs derived from plants, used in traditional medicine in the past and present, are becoming increasingly important alternatives for cancer treatments due to their low toxicity and costs ${ }^{[3-5]}$. The genus Ornithogalum is a member of the family Liliaceae. Various genera from this family are found in Europe, Asia and Africa, depending on climatic conditions. Sixty-two species from the genus are found in Turkey, with an endemism rate of $53 \%{ }^{[6]}$. Ornithogalum balansae (O. Balansae) is a plant that widely grows in Rize-Ovit region of

*Address for correspondence

E-mail: saliha.eksi@erdogan.edu.tr.com

March-April 2020
Northeastern Turkey. Historically, Ornithogalum tubers were used as medicine for the treatment of boils and vomiting in the time of Dioscorides in the 1st century $\mathrm{AD}^{[7]}$. In vitro screening by the National Cancer Institute (NCI) reported that one component from ornithogalum saundrasae bulbs exhibited cytostatic effect on 60 cell lines ${ }^{[8]}$. Mimaki et al. performed a similar study and showed that different components obtained from $O$. saundrasae bulbs exhibited cytostatic effects under in vivo and in vitro conditions ${ }^{[9]}$. Other authors have also emphasized that extracts or components obtained from various Ornithogalum species may exhibit

This is an open access article distributed under the terms of the Creative Commons Attribution-NonCommercial-ShareAlike 3.0 License, which allows others to remix, tweak, and build upon the work non-commercially, as long as the author is credited and the new creations are licensed under the identical terms

Accepted 04 February 2020

Revised 17 January 2020

Received 09 July 2019

Indian J Pharm Sci 2020;82(2):321-328 
cytotoxic effects on cancer cells ${ }^{[10-13]}$. Iguchi et al., Zhang et al., and Koyuncu et al. recently predicted that plants from the genus Ornithogalum may represent important sources as anticancer agents ${ }^{[14-17]}$. This study employed the colorimetric MTT method to investigate the cytotoxic and antiproliferative effects of methanol $(\mathrm{MeOH})$ and ethyl acetate (EtOAc) extracts from O. balansae flowers and bulbs on A549, CRL-2923, HT-29 and HeLa cell lines and the normal ARPE-19 cells. Findings of this study revealed that these extracts exhibited antiproliferative effect on the A549 lung cancer cell line. Literature review revealed that no studies were published previously which reported on $O$. balansae cytotoxicity making this study the first observation on this subject.

\section{MATERIALS AND METHODS}

Dimethyl sulfoxide (DMSO), 3-(4,5-dimethylthiazol2-yl)-2,5-diphenyltetrazolium bromide (MTT), taxol, Dubecco phosohate-buffered saline (D-PBS) and trypan blue were obtained from Sigma-Aldrich (USA). RPMI-1640 (Hyclone), fetal bovine serum (FBS), streptomycin, penicillin and trypsin-EDTA were purchased from Gibco (USA). Caspase-3 assay kit was purchased from Biovision (Milpitas, CA, USA). Wizard Genomic DNA purification kit was purchased from Promega (Madison, USA). DAPI (4',6-diamidino2-phenylindole dihydrochloride) was obtained from Vectashield H-1200 (Vector Lab, Burlingame, CA).

\section{Preparation of plant extracts:}

O. balansae flowers and bulbs were collected from Ovit/Rize, Turkey, between 26.5.2017 and 7.6.2017 and were stored frozen at $-20^{\circ}$. For extraction, about $20 \mathrm{~g}$ of plant parts were crushed in a mortar. Extractions were carried out with $100 \mathrm{ml}$ of $\mathrm{MeOH}$ and EtOAc with stirring on a magnetic platform (WiseStrir MSH 20A) set to100 rpm for $48 \mathrm{~h}$ at room temperature. Following filtration of the extracts the solvents were removed in a rotary vacuum evaporator (LabTech EV311) at $40^{\circ}$. Stock solutions of the extracts thus obtained were then stored at $-20^{\circ}$ in DMSO.

\section{Cell lines and cell culture:}

The adenocarcinoma alveolar basal epithelial (A549) and cervical cancer epithelial cell lines (HeLa) were obtained from Yeditepe University, Istanbul, Turkey. The endometrial adenocarcinoma cell line (CRL-2923) was obtained from Istanbul University, Turkey. The colon adenocarcinoma cell line HT-29 was purchased from the American Type Culture Collection (ATCC) and the diploid ARPE-19 retinal pigment epithelial cell line was received from Turgut Özal University, Ankara, Turkey. All cell lines are of human origin. Cell lines were maintained in RPMI-1640 with $10 \%$ FBS and $100 \mu \mathrm{g} / \mathrm{ml}$ streptomycin and $100 \mathrm{U} / \mathrm{ml}$ penicillin in T25 flasks at $37^{\circ}$ in $5 \% \mathrm{CO}_{2}$ (Thermo Fisher, USA). All cellular incubations were carried out under the same conditions unless otherwise indicated. Confluent cells were detached using $0.25 \%$ trypsin-EDTA solution for serial passage.

\section{Morphological studies:}

Morphological studies were carried out as described previously ${ }^{[18]}$. Briefly, A549, CRL-2923, HT-29, HeLa and ARPE-19 cell lines were first stained with trypan blue and counted using a hemocytometer. Cell suspensions were dispensed at $1 \times 10^{4}$ cells $/ \mathrm{ml}$ per well of 24-well microplates and incubated for $24 \mathrm{~h}$. At the end of the incubation, the medium was replaced with fresh medium. The negative (medium alone, and medium with $0.1 \%$ DMSO) and positive ( $5 \mathrm{nM}$ taxol) controls along with $O$. balansae extracts (flower and bulb) were prepared in the media at the desired concentrations and added to the cells. Morphological changes occurring in the cells were examined after $48 \mathrm{~h}$ under an inverted microscope (Olympus CKX41, 10X lens) and the results were photographed with an Olympus SCI30 camera. Cellular morphological changes were recorded.

\section{MTT cytotoxicity assay:}

The transformed and non-transformed ARPE-19 cells were dispensed in 96-well microplates at $1 \times 10^{4}$ cells/ $\mathrm{ml}$, and cells at $2 \times 10^{4}$ cells $/ \mathrm{ml}$, respectively. Following $48 \mathrm{~h}$ incubation, controls and the $\mathrm{MeOH}$ and EtOAc extracts of flowers $(50 \mu \mathrm{g} / \mathrm{ml})$ and bulbs $(100 \mu \mathrm{g} /$ $\mathrm{ml}$ ) were added into the wells of row A, which were serially diluted and incubated for $48 \mathrm{~h}$. At the end of this period, $10 \mu 1$ of $5 \mathrm{mg} / \mathrm{ml}$ MTT stock prepared in water was added to each well, followed by further $4 \mathrm{~h}$ incubation $^{[19]}$. Then, $100 \mu 1 \mathrm{DMSO}$ was added to each well to dissolve the formazan crystals developed in the living cells. Absorbance was measured at $570 \mathrm{~nm}$ in a multiscan plate reader (BioTek). Growth inhibition was calculated using the formula, (control well absorbancetest well absorbance)/control well absorbance) $\times 100^{[20]}$. The cytotoxic concentrations of the extracts, which inhibited cell growth by $50 \%\left(\mathrm{IC}_{50}\right)$ were calculated from the dose-response curve. The selective index (SI) was calculated from the ratio of the $\mathrm{IC}_{50}$ of the normal cells over the cancer cells. 


\section{Cell migration assay:}

ARPE-19 and A549 cells were added to 24-well plates as described above. After the cells reached 60-70\% confluence, the monolayer was scratched with a sterile tip $(10 \mu \mathrm{l})$. The $\mathrm{MeOH}$ extract of flowers $(3.5 \mu \mathrm{g} / \mathrm{ml})$, DMSO and taxol were then added to the wells. After $48 \mathrm{~h}$, scratch-healing was recorded using an inverted microscope.

\section{DNA fragmentation assays, gel electrophoresis:}

The cells were incubated for $48 \mathrm{~h}$ with $\mathrm{MeOH}$ extract of flower $(3.5 \mu \mathrm{g} / \mathrm{ml})$, bulb $(2 \mu \mathrm{g} / \mathrm{ml})$, and EtOAc extract of bulb $(1.5 \mu \mathrm{g} / \mathrm{ml})$ along with controls. DNA was isolated from cells using a Wizard genomic DNA purification kit according to manufacturer's protocol. Specimens were loaded onto $1 \%$ agarose gels with a DNA ladder. $(0.1-1.5 \mathrm{~kb})$, run at $90 \mathrm{~V}$. DNA fragmentation patterns were visualized on a UV transilluminator (Bio-Imaging system/MiniNumi) and photographed.

\section{DAPI staining:}

The cells were added to 6-well culture plates and incubated for $48 \mathrm{~h}$ with $\mathrm{MEOH}$ and EtOAc extracts of bulb (2 and $1.5 \mu \mathrm{g} / \mathrm{ml}$, respectively) along with the controls. At the end of this period, the cells were detached by trypsinization and transferred into Eppendorf tubes. After rinsing with cold PBS twice, they were fixed in cold $\mathrm{MeOH}\left(-20^{\circ}\right)$ on ice for $20 \mathrm{~min}$. The fixative was removed by centrifugation and rinsing with PBS. DAPI-stained cells were examined under a Leica LM 4000B fluorescence microscope and were photographed using a Leica DFC425 camera at 20X magnification.

\section{Caspase- 3 activation assay:}

Caspase-3 activity in cell lysates was measured using a caspase-3 colorimetric assay kit. This method is based on determining the breakdown of the substrate DEVDAFC (AFC: 7-amino-4-trifluoromethyl coumarin). Cells in $25 \mathrm{~cm}^{2}$ culture flasks treated with controls along with $\mathrm{MeOH}$ flower extract $(3.5 \mu \mathrm{g} / \mathrm{ml})$ for $48 \mathrm{~h}$. The cells were then pelleted at $1000 \mathrm{rpm}$ for $5 \mathrm{~min}$ and incubated with lysis buffer for $10 \mathrm{~min}$ on ice. Lysates were centrifuged for $1 \mathrm{~min}$ at $15.000 \mathrm{rpm}$ and, the supernatants stored at $-80^{\circ}$ for future use. Caspase- 3 activity was measured according to the manufacturer's instructions of the kit. Aliquots of cell extracts containing $100 \mu \mathrm{g}$ of protein were added to reaction buffer and incubated at $37^{\circ}$ for 1-2 $\mathrm{h}$. Absorbance values were read at $405 \mathrm{~nm}$ on an ELISA reader (BioTek).

\section{Statistical analysis:}

Results were analyzed using Student's unpaired t-test in GraphPad. All MTT experiments were carried out in triplicate. $\mathrm{p}$ values $\leq 0.05$ were considered statistically significant. The data were presented as mean $\pm \mathrm{SD}$.

\section{RESULTS AND DISCUSSION}

In recent years, studies of medicinal herbs and the extracts obtained from plants have become increasingly important. In this context, the antiproliferative properties of the extracts obtained from $O$. balansae flowers and bulbs were investigated. Initially, the cells were treated with $\mathrm{MeOH}$ extract of the flower $(3.5 \mu \mathrm{g} / \mathrm{ml})$ and bulb $(2 \mu \mathrm{g} / \mathrm{ml})$ and EtOAc extracts of the bulb $(1.5 \mu \mathrm{g} / \mathrm{ml})$ with the controls. After $48 \mathrm{~h}$ of incubation, the effects of the extracts were determined by observing the changes in cell morphology under an inverted microscope. The results are presented in fig. 1. There were no morphological changes in the non-transformed and the transformed cells treated with negative controls. However, taxol caused rounding and detachment of the transformed cells without affecting the non-transformed ARPE-19 cells. Exposure of the cells to $\mathrm{MeOH}$ flower extract caused morphological alterations in A549, HT-29 and HeLa cells, but had no apparent effect on the other cells. Meanwhile, both extracts of the bulb caused morphological alterations and detachment of the A549 cells alone. Since rounding and detachment of the cells from the surface are some of the characteristic features of apoptosis, these findings suggest that $O$. balansae extracts induced apoptotic cell death in A549, HT-29 and HeLa cells. Subsequently, the effects of the flower and bulb extracts on the nontransformed and the transformed cells were tested for $48 \mathrm{~h}$. The cytotoxic effects were investigated in vitro using the MTT proliferation assay and the results presented in fig. 2 showed antiproliferative effects of $\mathrm{MeOH}$ and EtOAc flower extracts on the cell lines. Serial dilutions ranging from a $500.8 \mu \mathrm{g} / \mathrm{ml}$ showed that both extracts exhibited dose-dependent cytotoxic effects against to the transformed and non-transformed cells at higher concentrations. Even though, both extracts induced anti-proliferative activities against CRL-2923, HT-29 and A549 cell lines, the most affected cell line was found to be the alveolar adenocarcinoma cells (A549). While $\mathrm{MeOH}$ and EtOAc extracts induced 58 and $45 \%$ growth inhibition in A549 cells, respectively, at a concentration of $1.56 \mu \mathrm{g} / \mathrm{ml}$. However, these two extracts reduced cell viability only by 16.4 and $17.5 \%$ in the non-transformed ARPE-19 cells, respectively. 


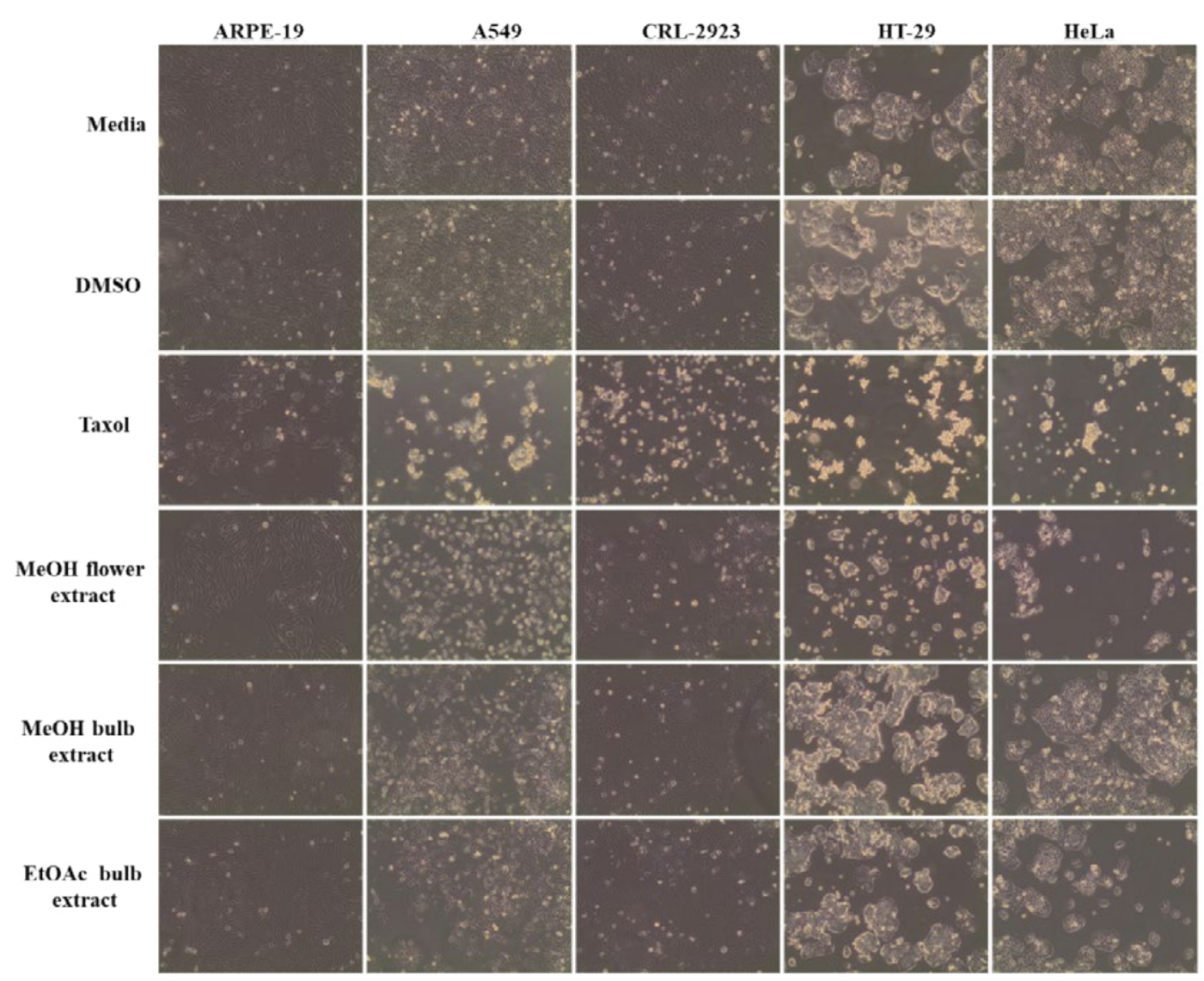

Fig. 1: Pictomicrographs of the effects of $O$. balansae extracts and controls on Cell line morphology

The effects of $O$. balansae extracts and the controls on the morphology of the non-transformed and transformed cell lines. After 48-h incubation, morphological changes in the cells were observed under an inverted microscope (magnification 10×). Media, DMSO 0.1\% (negative controls), taxol $5 \mathrm{nM}$ (positive control), MeOH extract of flower $(3.5 \mu \mathrm{g} / \mathrm{ml})$, MeOH extract of bulb $(2 \mu \mathrm{g} / \mathrm{ml})$, EtOAc extract of bulb $(1.5 \mu \mathrm{g} / \mathrm{ml})$. Images are representative of two independent experiments.
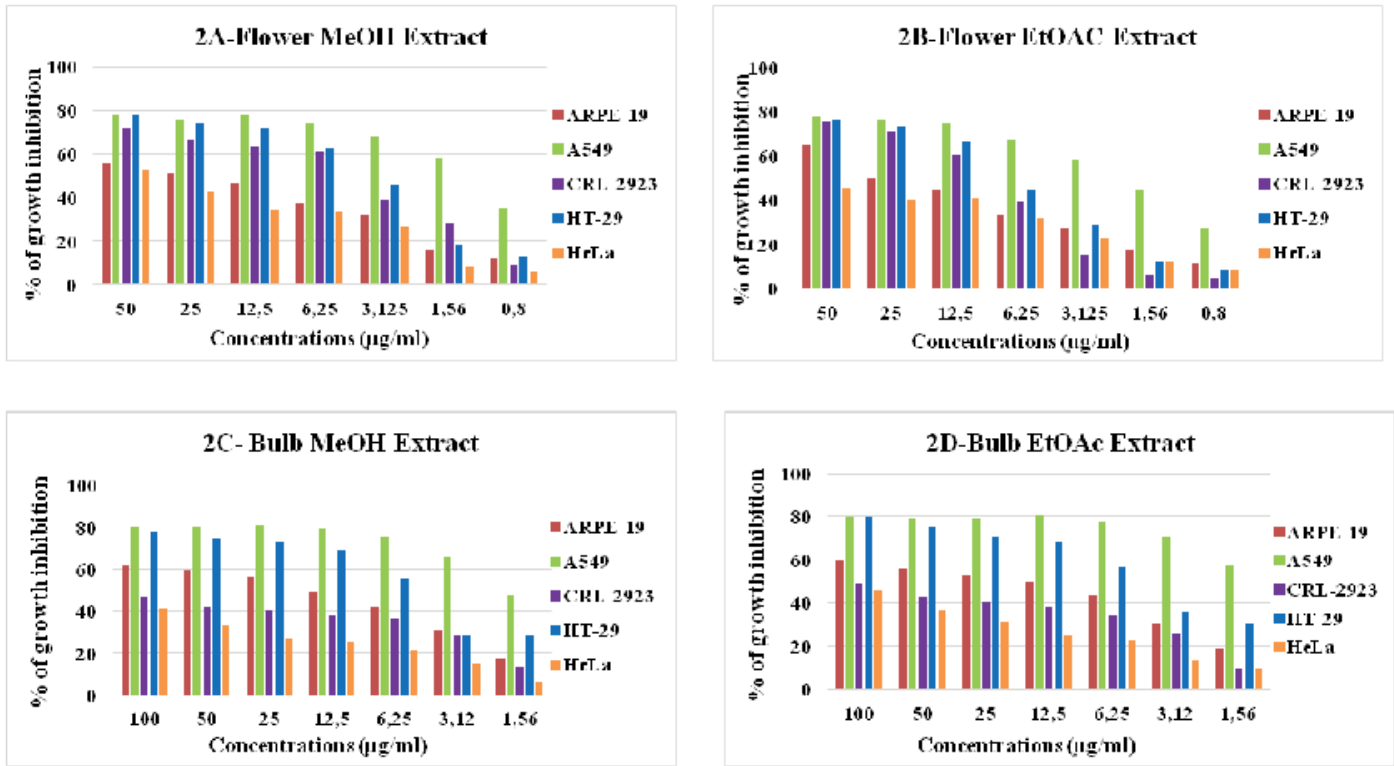

Fig. 2: Dose-dependent cytotoxic effects of $O$. balansae extracts on viability of cell lines

Dose-dependent cytotoxic effects of $\boldsymbol{O}$. balansae extracts on cell viability of the nontransformed and transformed cell lines determined using the MTT assay. The cells were exposed to extracts or the equivalent amount of DMSO for $48 \mathrm{~h}$. Data expressed as the average of at least 3 independent experiments with 2 replicates at each point ( $\square)$ ARPE-19, ( $\square)$ A549, ( $\square$ ) CRL-2923, ( $\square$ ) HT-29, ( $\square$ ) HeLa 
Meanwhile, HeLa cells were less sensitive to the treatment. Table 1 shows $\mathrm{IC}_{50}$ and $\mathrm{SI}$ values. In terms of cytotoxicity, statistical analysis of the $\mathrm{IC}_{50}$ values from $\mathrm{MeOH}$ and EtOAc extracts revealed significant differences between ARPE-19 and A549, with values of 22.5 $\pm 6.466, \quad 1.5 \pm 0.153$, and $25.0 \pm 2.887$ and $2.2 \pm 0.503 \mu \mathrm{g} / \mathrm{ml}$, respectively $(\mathrm{p}<0.05)$. Results also showed that differences between ARPE-19 and the other cancer cells were significant except for HeLa cells $(p<0.05)$. As shown in fig. 2 treatment with $\mathrm{MeOH}$ and EtOAc bulb extracts for $48 \mathrm{~h}$ resulted in a concentration-dependent decline in cell viability. On the other hand, it was found that both these extracts induced prominent cytotoxic effects on A549, even at $3.12 \mu \mathrm{g} / \mathrm{ml}$ with growth inhibition of 65.6 and $70.5 \%$, respectively. Statistical analysis of the $\mathrm{IC}_{50}$ values from $\mathrm{MeOH}$ and EtOAc extracts indicated significant differences between ARPE-19 and A549, with values of $14.0 \pm 4.726,1.8 \pm 0.404 \mu \mathrm{g} / \mathrm{ml}$ and $12.5 \pm 3.182$, $1.56 \pm 0.106 \mu \mathrm{g} / \mathrm{ml}$, respectively $(\mathrm{p}<0.05)$. Results also showed that differences between ARPE-19 and HT-29 cells were significant $(\mathrm{p}<0.05)$. These results suggested

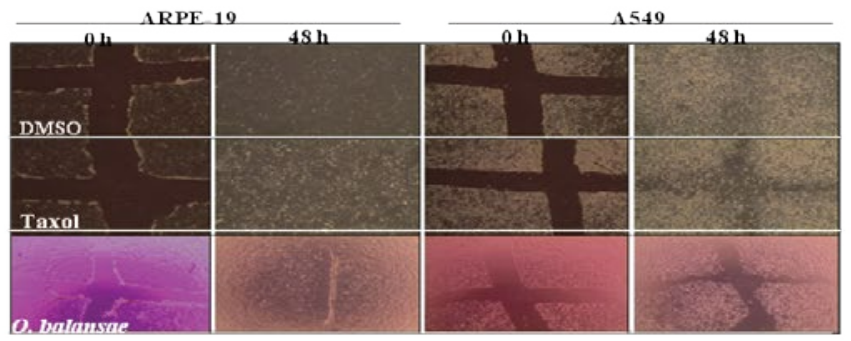

$3 A$

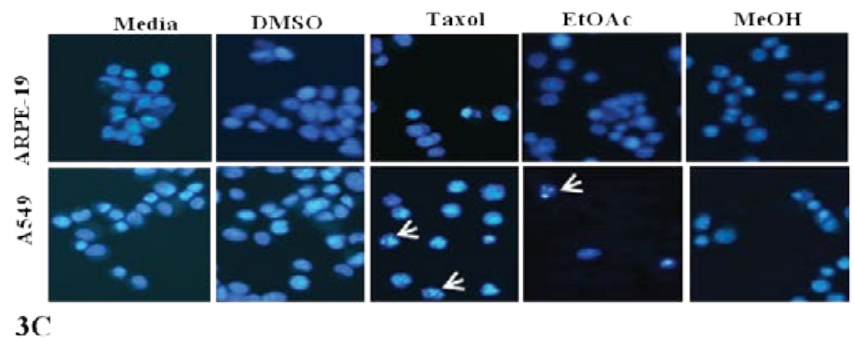

that extracts of $O$. balansae were very effective against human alveolar adenocarcinoma cell line (A549). Proliferation assay results indicated that the extracts inhibited growth of the cancer cell lines. Notably, among the cancer cell lines, A549 was found to be the most susceptible to all extracts. On the other hand, these extracts induced very low cytotoxicity against HeLa cells. Previous reports emphasized the heterogeneity and tissue specificity of cancer cell lines with respect to responses to chemical drugs ${ }^{[21]}$. It is therefore possible that tumor cell lines originated from different tissues exhibited different degrees of sensitivities toward the same extracts. Furthermore, it was also found that these extracts induced low growth inhibition in normal ARPE-19 cells. According to the available data, it is well known that current cancer drugs not only affect the cancer cells but also are cytotoxic to healthy human cells $^{[22] .}$. In the present study, wound healing in the ARPE19 and A549 cell lines with $\mathrm{MeOH}$ flower extracts and controls was evaluated. As shown in fig. 3A, the wound in the extract-treated ARPE-19, but not A549, cells resolved almost entirely. In recent years, there has been

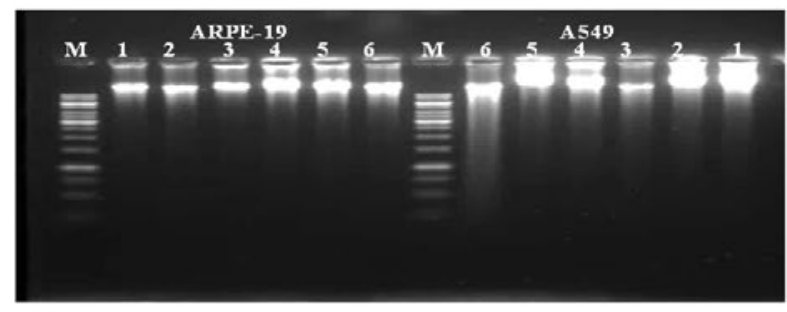

3B

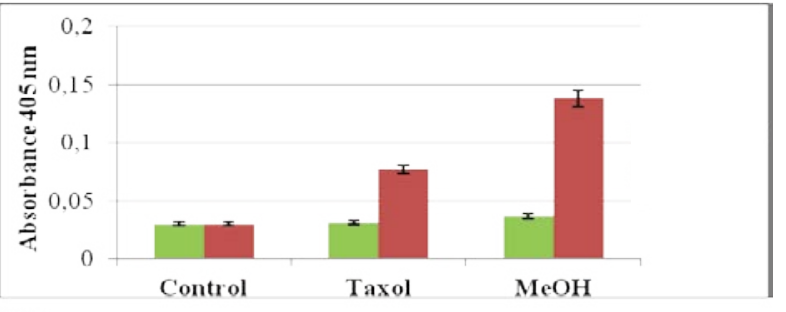

3D

Fig. 3: Effects of the flower MeOH extract, DMSO or taxol on cell migration, DNA fragmentation, apoptosis and caspase-3 activity

Effects of the flower MeOH extract $(3.5 \mu \mathrm{g} / \mathrm{ml})$, DMSO or taxol on 3A) cell migration as inverted microscope images at magnification 4X (ש) ARPE-19 and (ロ) A549, 3B) Effects of the extracts, taxol, medium or the equivalent amount of DMSO on DNA fragmentation in ARPE-19 and A549 cells. M is marker, media (1), DMSO (2), MeOH extract of flower (3), MeOH extract of bulb (4), EtOAc extract of bulb (5) and Taxol (6). 3C) Cell apoptosis observed using fluorescence microscope (20X). For detection of apoptosis, ARPE-19 and A549 cells were incubated with the MeOH extracts, (flower $2 \mu \mathrm{g} / \mathrm{ml} /$, bulb $1.5 \mu \mathrm{g} / \mathrm{m}$ ), medium, taxol $(5 \mathrm{nM}$ ), or the equivalent amount of DMSO for $48 \mathrm{~h}$. The apoptotic cells were observed under fluorescence microscope after DAPI staining Arrows indicate the apoptotic cells (condensed/ fragmented nuclei). 3D) Shows caspase-3 activity in the lysates of ARPE-19 and A549 cells treated with controls (taxol, DMSO) and MeOH extract of the flower $(3.5 \mu \mathrm{g} / \mathrm{ml})$. Results are expressed as mean \pm SD from 3 independent experiments. Taxol and flower MeOH extract induced statistically significant differences between ARPE19 and A549cells $(\mathbf{p}<0.05)$. 
considerable interest in treatment-induced apoptosis. Therefore, in this study the effect of the extracts on apoptosis was evaluated using DNA fragmentation assays (gel electrophoresis and DAPI stainning) and caspase- 3 activity test. gel electrophoresis results are presented in fig. 3B. DNA isolated from the A549 or ARPE-19 cells was treated with $\mathrm{MeOH}$ extracts of flower $(3.5 \mu \mathrm{g} / \mathrm{ml})$ and bulb $(2 \mu \mathrm{g} / \mathrm{ml})$ and bulb EtOAc extract $(1.5 \mu \mathrm{g} / \mathrm{ml})$, along with the controls. Data showed laddering by the positive control, taxol in A549 cells. The extracts and the negative controls caused no DNA fragmentation in any of the cell lines. In this study, In the DAPI staining assay, ARPE-19 and A549 cell lines were treated with bulb $\mathrm{MeOH}$ $(2 \mu \mathrm{g} / \mathrm{ml})$ and EtOAc $(1.5 \mu \mathrm{g} / \mathrm{ml})$ extracts and the controls for $48 \mathrm{~h}$ before DAPI staining. Then, these were stained with DAPI and DNA chromatin condensation was examined under a fluorescence microscope. Chromatin condensation was evident only in A549 cells treated with taxol and not the extracts or negative controls (fig. 3). As shown in fig. 3, taxol, resulted in DNA chromatin condensation in A549 cancer cells but had no effect on non-transformed ARPE-19 cells. Although both extracts decreased A549 cell number considerably compared to the negative controls, they did not result in characteristic DNA chromatin condensation in A549 cells. One possible reason for this finding might be that most of the extract-treated A549 cells lysed during the experimental procedure. Therefore, quantification of the apoptotic cells is not considered appropriate. To further validate apoptosis, the activity of caspase-3 was measured in A549 and ARPE-19 cell lines treated with $\mathrm{MeOH}$ extracts of flower $(3.5 \mu \mathrm{g} / \mathrm{ml})$ and the controls. As shown in fig. 3D, no caspase-3 activity was observed in the ARPE-19 cells under any conditions but in the A549 cell line treated with taxol and the extracts. Statistical analysis of absorbance values for the $\mathrm{MeOH}$ extract revealed significant difference in caspase-3 activity between the ARPE-19 $(0.037 \pm 0.00721)$ and A549 $(0.138 \pm 0.01401)$ cell lines $(p<0.05)$. More importantly, caspase- 3 activity in the A549 cells treated with extract was 1.8-fold higher than the taxol treated ones. These results suggested that treatment with extract could lead to apoptosis of the A549 cells, probably through caspase-dependent pathway.

WHO reported that there were 2.09 million cases of lung cancer worldwide and that 1.76 million of these died from the disease in $2018^{[2]}$. New therapeutic strategies are becoming increasingly important due to the increasing mortality and morbidity due to lung cancer in both men and women. Despite all the progress made in modern medicine, plant-based alternative therapies are still popular and interest in these has grown in recent years. Natural compounds used for the treatment or prevention of cancer are therefore growing in importance as potential drugs. For example, taxol (paclitaxel), which is still in use today, is a wellknown anticancer drug of natural origin obtained from the bark of Taxus brevifolia. It causes minimal side effects and is a potent anticancer agent for the treatment of lung, ovarian, and breast cancer in millions of patients worldwide ${ }^{[3,4]}$. Although there have been very few studies concerning some species from the genus Ornithogalum, we found no cytotoxicity studies of O. balansae, which widely grows in Rize Province in Turkey. In vitro screening by the NCI in 1992 revealed a cytostatic effect of OSW-1 (a member of the cholestane saponin family) obtained from Ornithogalum plants on 60 cell lines ${ }^{[8]}$. Deng et al. reported that OSW-1 analogs exhibited greater effects on AGS (stomach), 7404 (liver) and MCF (breast) cancer cells than cisplatin ${ }^{[23]}$. Mimaki et al. showed that different components obtained from $O$. saundrasae bulbs exhibited cytostatic effects under in vivo and in vitro conditions ${ }^{[9]}$. Two different studies of $O$. caudatum Ait were performed in 2010 and 2017. In the first, Chen et al. reported that polysaccharide fractions exhibited antitumor activity against 180 solid tumors under in vivo conditions and also possessed significant antiproliferative effects against K562 leukemia cells in vitro ${ }^{[12]}$. In the second study, Zhang et al. used OSW-1, a steroidal glycoside obtained from O. caudatum Ait and showed that to be effective against colon cancer in vivo and in vitro ${ }^{[16]}$.

Koyuncu et al. reported that total extract from $O$. narbonense L. a different species, shoots exhibited a mild effect on HEK-293 (normal embryonic kidney cells) but exhibited high cytotoxic effects on DLD-1 (colon) and ECC-1 (endometrium) cancer cell lines ${ }^{[17]}$. It has been reported that a compound or a plant extract that possesses dose-dependent cytotoxic effect and an $\mathrm{IC}_{50}$ value less than $10 \mu \mathrm{g} / \mathrm{ml}$ should be considered to as antiproliferative against cancer cells ${ }^{[24]}$. In the present study, $\mathrm{IC}_{50}$ values of $\mathrm{MeOH}$ and EtOAc extracts obtained from $O$. balansae flowers on A549 cells were $1.5 \pm 0.153$ and $2.2 \pm 0.503 \mu \mathrm{g} / \mathrm{ml}$, respectively, while the extracts of bulbs showed $1.80 \pm 0.404$ and 1.56 $\pm 0.106 \mu \mathrm{g} / \mathrm{ml}$, respectively. On the other hand, the 
$\mathrm{IC}_{50}$ values of the same extracts in ARPE-19 cells were $22.5 \pm 6.66,25 \pm 2.887 \mu \mathrm{g} / \mathrm{ml}$ and $14 \pm 4.726$ and $12.5 \pm 3.182 \mu \mathrm{g} / \mathrm{ml}$, respectively. As an $\mathrm{IC}_{50}$ value $<10 \mu \mathrm{g} / \mathrm{ml}$ is considered significant for an anticancer agent, $O$. balansae extracts are potential anticancer agents, at least for the A549 cell line. SI values of the extracts (Table 1) confirmed that the extracts have strong antiproliferative activity against A549 cells, ranging from 15 to 8.33. It has been reported that an extract with an SI value of $\geq 3$ is considered to have better biological activity against tumor cells than the normal cells under in vitro conditions ${ }^{[25]}$. The results of the present study are in line with previous studies including those of Mimaki et al., and Iguchi et al., which showed that some components of the genus Ornithogalum exhibit high antiproliferative effects against the A549 lung cancer cell line ${ }^{[9,14]}$. This is contrary to the study of Andriamisaina et al. who reported that steroid glycosides obtained from $O$. dubium Hount did not cause growth inhibition in the A549 cell line ${ }^{[26]}$. Metastatic lung cancer resists treatments and spreads to distant sites ${ }^{[27]}$. The antimigration properties of these extracts were investigated in this study. The $\mathrm{MeOH}$ flower extract was effective in closing the scratch made in ARPE-19, but not A549 cells after $48 \mathrm{~h}$ (fig. 3). These are compatible with the MTT results and showed that $\mathrm{MeOH}$ flower extracts prevented migration of A549 cells. It has been reported that plant extracts cause antiproliferation by using the apoptotic or necrotic pathways ${ }^{[28-30]}$. This study investigated whether $O$. balansae flower/bulb extracts exhibit an inhibitory effect on A549 cells using the apoptotic pathway by employing DNA fragmentation and caspase-3 measurements. Some recent studies have shown that some components of the plant Ornithogalum exert cytotoxic effects by activating apoptosis ${ }^{[13,15]}$. Iguchi et al. showed that a compound obtained from $O$. saundrasae induced apoptosis by causing DNA fragmentation in HL-60 cells, but not in A549 cells ${ }^{[15]}$. The gel electrophoresis and fluorescence experimental results in this study showed that the extracts, unlike taxol, failed to cause DNA fragmentation in both control and A549 cell lines (fig. 3). Studies have reported that as cancer cells proceed toward apoptosis, fragmentation of the DNA may occur an early or late stages ${ }^{[31,32]}$. Since the antiproliferative effects of $O$. balansae extracts on non-transformed and transformed cells cannot be determined using the DNA fragmentation method, the caspase-3 activity test, a more specific method was used in which apoptosis could be tested. Caspase-3 is well known to function as a key protein in the apoptotic pathway. As shown in fig. 3, the MeOH flower extract did not lead to caspase-3 activity in non-transformed cells, but in A549 cancer cells, which was greater than taxol. The results of this study demonstrated that the medicinal plant $O$. balansae has potential antiproliferative activity, particularly against the A549 cell line. The component(s) in the extract with anticarcinogenic potential might have different pharmacodynamic activities, which could be either synergestic or antagonistis interactions with each another. Despite these encouraging results, extensive investigations are needed for determining the bioactive compounds in the extracts. As a first report showing a very potent anticancer activity of $O$. balansae extracts against A549 cells, the investigation could provide promising improvements in cancer therapy.

\section{Acknowledgments:}

This work was supported by Recep Tayyip Erdoğan University Research Fund Grants (BAP2015.53001.106.01.04). The authors express their gratitude to Prof Dr Fikrettin Şahin, Yeditepe University, Istanbul, Turkey for A549, He-La cell lines, to Prof Dr Bedia Ağaçhan Çakmakoğlu, Istanbul University, Turkey for the endometrial adenocarcinoma cell line, CRL-2923 and to Dr Muradiye Acar, Turgut Özal University, Ankara, Turkey for providing the diploid ARPE-19 retinal pigment epithelial cell line.

TABLE 1: IC ${ }_{50}$ AND SELECTIVITY INDEX (SI) VALUES OF O. BALANSAE EXTRACTS

\begin{tabular}{|c|c|c|c|c|c|}
\hline Extracts & ARPE-19 & A549 & CRL-2923 & HT-29 & HeLa \\
\hline Flower $\mathrm{MeOH}$ & $22.5 \pm 6.466$ & $\begin{array}{c}1.5 \pm 0.153^{*} \\
(15)\end{array}$ & $\begin{array}{c}5.1 \pm 0.813^{*} \\
(4.41)\end{array}$ & $\begin{array}{c}4.2 \pm 1.626^{*} \\
(5.4)\end{array}$ & $\begin{array}{c}42 \pm 7.071 \\
(0.54)\end{array}$ \\
\hline Flower EtOAc & $25 \pm 2.887$ & $\begin{array}{c}2.2 \pm 0.503^{*} \\
(11.4)\end{array}$ & $\begin{array}{c}9.5 \pm 2.710^{*} \\
(2.63)\end{array}$ & $\begin{array}{c}7.5 \pm 1.750^{*} \\
(3.33)\end{array}$ & ND \\
\hline Bulb $\mathrm{MeOH}$ & $14 \pm 4.726$ & $\begin{array}{c}1.8 \pm 0.220^{*} \\
(7.78)\end{array}$ & ND & $\begin{array}{c}5.6 \pm 0.252 * \\
(2.5)\end{array}$ & ND \\
\hline Bulb EtOAc & $12.5 \pm 3.182$ & $\begin{array}{c}1.56 \pm 0.106^{*} \\
(8.33)\end{array}$ & ND & $\begin{array}{c}5.3 \pm 0.495^{*} \\
(2.4)\end{array}$ & ND \\
\hline
\end{tabular}

$\mathrm{ND}$ is not detectable, The $\mathrm{IC}_{50}$ values are presented as mean $\pm \mathrm{SD}$. SI values are in parenthesis, ${ }^{*}$ indicate significant differences between ARPE19 and transformed cell lines 


\section{REFERENCES}

1. Klug WS, Cummings MR, Spencer CA, Palladino MA. Concept of genetics10th ed. Pearson Education Limited; 2014.

2. World Health Organization Global cancer. International Agency for Research on Cancer. Latest global cancer data: Cancer burden rises to 18.1 million new cases and 9.6 million cancer deaths in 2018.

3. S Nataru, Y Pulicherla, B Gaddala. A Review on Medicinal Plants as a Potential Source for Cancer. Int J Pharm Sci Rev Res 2014;26(1):235-48.

4. Thapliyal A, Krishen Khar R, Chandra A. Overview of Cancer and Medicinal Herbs used for Cancer Therapy. Asian J Pharm Sci 2018;12(1):S1-S8.

5. Greenwell M, Rahman PKSM. Medicinal Plants: Their Use in Anticancer Treatment. Int J Pharm Sci Res 2015;6(10):410312.

6. Demirci S. Pharmaceutical Botanical Studies on the family Hyacinthaceae. İstanbul University, Institute of Health Science 2014.

7. Baytop T. Türkiye'de Bitkiler İle Tedavi. Nobel Tıp Kitabevleri, İstanbul, 1999.

8. Boyd MR, Paull KD, Rubinstein LR. Cytotoxic Anticancer Drugs: Models and Concepts for Drug Discovery and Development. Kluwer Academic Publishers, Amsterdam 1990; pp. 11-34.

9. MimakiY, Minpei K, Kameyama A, Sashida Y, Hirano T, Oka K, et al. Cholestane Glycosides With Potent Cytostatic Activities On Various Tumor Cells From Ornithogalum Saundrasae Bcvbn bulbs. Bioorg Med Chem Lett 1997;7(5):633-6.

10. Hirano T, Oka K, Mimaki Y, Kuroda M, Sashida Y. Potent Growth Inhibitory Activity Of A Novel Ornithogalum Cholestane Glycosside On Human Cells: Induction Of Apoptosis In Promyeloctic Leukemia HL-60 Cells. Life Sci 1996;58(9):789-98.

11. Kuroda M, Mimaki Y, Sashida Y. Saundersiosides C-H, rearranged cholestane glycosides from the bulbs of Ornithogalum saundersiae and their cytostatic activity on HL60 cells. Phytochemistry 1999;52:435-43.

12. Chen R, Meng F, Liu Z, Chen R, Zhang M. Antitumor activities of different fractions of polysaccharide purified from Ornithogalum caudatum Ait. Carbohydr Polyms 2010;80(3):845-51.

13. Asadi H, Orangi M, Shanehbandi D, Babaloo Z, Delazar A, Mohammadnejad L, et al. Methanolic Fractions of Ornithogalum cuspidatum Induce Apoptosis in PC-3 Prostate Cancer Cell Line and WEHI-164 Fibrosarcoma Cancer Cell Line. Adv Pharm Bull 2014;4:455-8.

14. Iguchi $T$, Kuroda $M$, Naito $R$, Watanabe $T$, Matsuo $Y$, Yokosuka A, et al. Structural Characterization of Cholestane Rhamnosides from Ornithogalum saundersiae Bulbs and Their Cytotoxic Activity against Cultured Tumor Cells. Molecules 2017;22(8):1243.

15. Iguchi T, Kuroda M, Naito R, Watanabe T, Matsuo Y, Yokosuka A, et al. Cholestane glycosides from Ornithogalum saundersiae bulbs and the induction of apoptosis in HL-60 cells by OSW-1 through a mitochondrial-independent signaling pathway. J Nat Med 2019;73:131-45.

16. Zhang Y, Fang F, Fan $\mathrm{K}$, Zhang Y, Zhang J, Guo H, et al.
Effective Cytotoxic Activity Of OSW-1 On Colon Cancer By Inducing Apoptosis In vitro and In vivo. Oncol Rep 2017;37:3509-19.

17. Koyuncu I, Gönel A, Akdağ A, Yilmaz MA. Identification of phenolic compounds, antioxidant activity and anti-cancer effects of the extract obtained from the shoots of Ornithogalum narbonense L. Cell Mol Biol 2018;64:75-83.

18. Ekşi S, Ejder N, Yilmaz F, Ertürk A, Sandalli C. PaCaHa inhibits proliferation of human cancer cells in vitro. Turk J Med Sci 2016;46(3):872-6.

19. Mossmann T. Rapid colorimetric assay for cellular growth and survival: Application to proliferation and cytotoxicity assays. J Immunol Methods 1983;65:55-63.

20. Zhou Y, Jie XJ, Xing C, Zhang D. Anticancer activity and mechanism of Scutellaria barbata extract on human lung cancer cell line A549. Life Sci 2004;75(18):2223-4.

21. Arul M, Roslani AC, Cheah SH. Heterogeneity in cancer cells: Variation in drug response in different primary and secondary colorectal cancer cell lines in vitro. In Vitro Cell Dev-An 2016; 53(5):435-47.

22. Nussbaumer S, Bonnabry PJ. Veuthey L, Fleury-Souverain S. Analysis of anticancer drugs: A review. Talanta 2011;85(5):2265-89.

23. Deng L, Wu H, Yu B, Jiang M, Wu J. Synthesis Of OSW-1 Analogs With Modified Side Chains And Their Antitumor Activirties. Bioorg Med Chem Lett 2004;14:2781-5.

24. Xing J-y, Song G-p, Deng J-p, Jiang L-z, Xiong P, Yang B-j, et al. Antitumor Effects and Mechanism of Novel Emodin Rhamnoside Derivatives against Human Cancer Cells In Vitro. PLoS ONE 2015;10(12):e0144781.

25. Bézivin CS, Tomasi F, Lohezic-Le D, Boustie J. Cytotoxic Activity Of Some Lichen Extracts On Murine and Human Cancer Cell Lines. Phytomedicine 2003;10:499-503.

26. Andriamisaina N, Mitaine-Offer AC, Miyamoto T, Tanaka C, Pululat T, Lirussi F, et al. Steroidal Glycosides From Ornithogalum dubitum Houtt. Phytochemistry 2019;160:7884.

27. Popper HH. Progression and metastasis of lung cancer. Cancer Metastasis Rev 2016;35:75-91.

28. Guamán-Ortiz LM, Orellana MIR, Ratovitski EA. Natural Compounds As Modulators of Non-apoptotic Cell Death in Cancer Cells. Curr Genomics 2017;18(2):132-155.

29. Khazaei S, Hamid RA, Ramachandran V, Esa NM, Pandurangan AK, Danazadeh F, et al. Cytotoxicity and Proapoptotic Effects of Allium atroviolaceum Flower Extract by Modulating Cell Cycle Arrest and Caspase-Dependent and p53-Independent Pathway in Breast Cancer Cell Lines. Evid Based Complementary Altern Med 2017:1468957.

30. Wang X, Feng Y, Wang N, Cheung F, Tan HY, Zhong S, et al. Chinese Medicines Induce Cell Death: The Molecular and Cellular Mechanisms for Cancer Therapy. BioMed Res Int 2014;14:1-14.

31. Elmore S. Apoptosis: A Review of Programmed Cell Death. Toxicol Pathol 2007;35(4):495-516.

32. Jae AC, Cynthia SA, Kristy KY, Vesely J, Mark CW. Major DNA Fragmentation Is a Late Event in Apoptosis. J Histochem Cytochem 1997;45(7):923-34. 